\title{
Discrimination between Normal Wildtype and Carriers of Coagulation Factor V Leiden Mutation by the Activated Protein C Resistance Test in the Presence of Factor V Deficient Plasma
}

\author{
Karl H. Reuner, Frank Litfin and Heinrich Patscheke
}

Medizinisch-Diagnostisches Institut, Klinikum Karlsruhe gGmbH, Karlsruhe, Germany

Summary: Blood samples from 104 patients with clinically suspected thrombophilia were analyzed for coagulation factor $\mathrm{V}$ Leiden mutation $(1691, \mathrm{G} \rightarrow \mathrm{A})$ by allele-specific polymerase chain reaction. In 86 individuals $(82.7 \%)$, the mutation was not detectable, whereas 15 patients $(14.4 \%)$ were heterozygous and three patients $(2.9 \%)$ were homozygous for factor V Leiden mutation. Plasma samples from these individuals were also tested for functional resistance of coagulation factor $\mathrm{V}$ to activated protein $\mathrm{C}$ (activated protein $\mathrm{C}$ resistance). This test was performed on a Schnitger-Gross coagulometer using an activated partial thromboplastin time-based activated protein $\mathrm{C}$ resistance test modified by applying a 1:5 dilution with factor V-deficiency plasma. All the individuals negative for factor V Leiden mutation were also negative in the functional activated protein $\mathrm{C}$ resistance test. On the other hand, all patients carrying the mutation revealed pathologic results in the activated protein $\mathrm{C}$ resistance test. The cutoff value for the activated protein $C$ resistance index ( $\geq 1.7=$ negative) was determined by testing 31 male and female blood donors. One of them was heterozygous for factor $\mathrm{V}$ Leiden mutation and had an activated protein $\mathrm{C}$ resistance index of 1.4, whereas those without factor $\mathrm{V}$ Leiden mutation had an activated protein $\mathrm{C}$ resistance index of $1.9 \pm 0.1(\bar{x} \pm S D)$. Patients with clinically suspected thrombophilia without factor $V$ Leiden mutation had an activated protein $C$ resistance index of $2.1 \pm 0.2(\overline{\mathrm{x}} \pm \mathrm{SD})$, whereas patients heterozygous for the mutation had an index of $1.5 \pm 0.1(\overline{\mathrm{x}} \pm \mathrm{SD})$. Within the group of patients carrying the mutation, the activated protein $C$ resistance test even distinguished between heterozygous and three homozygous (activated protein $\mathrm{C}$ resistance 1.0 to 1.2) carriers. The data demonstrate that the activated protein $\mathrm{C}$ resistance test in the presence of factor V-deficiency plasma provides a clear-cut discrimination between normal wildtype and carriers of factor $\mathrm{V}$ Leiden mutation with a sensitivity and specificity of $100 \%$. Verification of positive activated protein $\mathrm{C}$ resistance tests can be performed easily with a simple and reliable polymerase chain reaction protocol for the $1691, \mathrm{G} \rightarrow \mathrm{A}$ mutation.

\section{Introduction}

Resistance of coagulation factor $\mathrm{V}$ to activated protein $\mathrm{C}$ is reported to be the most prevalent coagulation abnormality associated with venous thrombosis and embolism. Activated protein $\mathrm{C}$ resistance is more prevalent than all other known coagulation abnormalities associated with venous thrombosis together. It occurs in at least $20 \%$ of patients with a history of thromboembolism, as well as in the asymptomatic general European population, at a prevalence of up to ten percent $(1-4)$.

As described by Bertina et al. (4), the phenotype of activated protein $C$ resistance is associated with a single point mutation in the coagulation factor $\mathrm{V}$ gene at nucleotide position 1691 (guanine (G) to adenine (A) substitution; $1691, \mathrm{G} \rightarrow \mathrm{A}$ ), resulting in the synthesis of a factor V molecule with the substitution of glutamine (Q) for arginine (R) at amino acid residue number 506, named factor V Q506 or factor V Leiden (4). The consequence of the mutation is loss of an activated protein $\mathrm{C}$ cleavage site at amino acid residue 506, resulting in an insufficient inactivation of membrane-bound activated factor V (factor Va) by activated protein $\mathrm{C}$. It is assumed that at least $90 \%$ of cases of functional activated protein $\mathrm{C}$ resistance are caused by the factor $\mathrm{V}$ Leiden mutation (1). Heterozygosity for the gene defect is associated with a 5- to 10-fold higher risk of thrombosis, whereas homozygosity for the mutation seems to be associated with a 50- to 100 -fold increased risk. The risk is further enhanced by other coagulation abnormalities such as deficiency of antithrombin III, protein C or protein S (1, 5-8). Because of cost-to-risk estimations, genotypic screening for factor $\mathrm{V}$ Leiden in women taking oral contraceptives has been suggested $(9-11)$.

Molecular biology based diagnosis of factor V Leiden mutation can be achieved by polymerase chain reaction analysis, for which many protocols have been described. Determination of activated protein $\mathrm{C}$ resistance might be used as well, since the mutation results in functional activated protein $\mathrm{C}$ resistance. However, it has been demonstrated that the conventional activated partial thromboplastin time-based activated protein $\mathrm{C}$ resistance assay 
is influenced by deficiency of coagulation factors, anticoagulatory therapy, lupus anticoagulant and protein $\mathrm{S}$ deficiency $(12-14)$. As a consequence, the activated protein $\mathrm{C}$ resistance test exhibits an unacceptably low sensitivity and specificity for the detection of the mutation. Thus, polymerase chain reaction techniques appeared to be indispensable for screening of factor $\mathrm{V}$ Leiden mutation in patients with suspected or manifested thrombophilia, especially when patients are under anticoagulatory therapy (13).

In order to avoid the influence of coagulation factor or protein $\mathrm{S}$ deficiencies, anticoagulation etc. in functional activated protein $\mathrm{C}$ resistance tests, some authors used patients' samples upon dilution with factor $\mathrm{V}$ deficient plasma $(15,16)$. This modification significantly improved sensitivity and specificity of the activated protein $\mathrm{C}$ resistance test. As a result, the modified activated protein $\mathrm{C}$-resistance test has been proposed as a screening method in diagnosis of factor $\mathrm{V}$ Leiden mutation (1519). On the other hand, it has been shown that the modified test does not clearly discriminate between normal wildtype and homozygous or heterozygous carriers of factor V Leiden mutation in each case (20). Other groups still use the unmodified activated protein $\mathrm{C}$-resistance test with its low sensitivity and specificity for the detection of factor V Leiden mutation $(21,22)$.

We used an activated partial thromboplastin time-based activated protein $\mathrm{C}$-resistance test modified by a $1: 5$ dilution of plasma samples with factor $\mathrm{V}$ deficiency plasma and performed it on a non-automatized Schnitger-Gross coagulometer. It was demonstrated that the modified activated protein $\mathrm{C}$ resistance test detects factor V Leiden mutation with a sensitivity and specificity of $100 \%$ and even discriminates heterozygous and homozygous forms of the mutation. Verification of the kind of mutation can be restricted to samples with positive activated protein $\mathrm{C}$ resistance tests and can be performed easily with the allele-specific polymerase chain reaction protocol used here.

\section{Materials and Methods}

\section{Materials}

The Chromogenix activated protein $\mathrm{C}$ resistance test kit (Coatest) and factor $\mathrm{V}$ deficiency plasma were obtained from Hämochrom Diagnostika (Essen, Germany). Polymerase chain reaction primers and dNTPs were purchased from Pharmacia (Freiburg, Germany). Proteinase K was supplied by Sigma (Munich, Germany). Taq polymerase was purchased from Gibco (Karlsruhe, Germany). All other chemicals were analytical or molecular biological grade and obtained from commercial sources.

\section{Study population and blood sampling}

Citrated plasma samples (venous blood : $0.1 \mathrm{~mol} / \mathrm{l}$ sodium citrate $=10: 1$ ) were obtained from male and female patients with clinically suspected thrombophilia referred to our laboratory, or from male and female blood donors for determination of reference values. Platelet-poor plasma was obtained by two centrifugation steps of $10 \mathrm{~min}$ each at $2000 \mathrm{~g}$ at room temperature. The plasma was collected carefully, strictly avoiding contamination with platelets. Aliquots were frozen at $-25^{\circ} \mathrm{C}$.

\section{Activated protein $\mathrm{C}$ resistance test}

Plasma samples were thawed immediately before testing by incubation at $37^{\circ} \mathrm{C}$ for exactly $10 \mathrm{~min}$. Each sample was prediluted with factor $\mathrm{V}$ deficiency plasma $(1: 5)$ to exclude effects of other factors than factor $V$ Leiden mutation on the activated protein $C$ resistance test. Diluted plasma samples $(100 \mu \mathrm{l})$ were mixed with $100 \mu 1$ prewarmed activated partial thromboplastin time reagent and incubated for $5 \mathrm{~min}$ at $37^{\circ} \mathrm{C}$. Coagulation on a SchnitgerGross coagulometer (Amelung, Lemgo, Germany) was started by adding either $100 \mu \mathrm{l} \mathrm{CaCl} 2(0.025 \mathrm{~mol} / \mathrm{l})$ or a mixture of activated protein $\mathrm{C}$ and $\mathrm{CaCl}_{2}$. The results were expressed as a ratio of the coagulation time obtained with the $\mathrm{CaCl}_{2}$-activated protein $\mathrm{C}$ mixture over $\mathrm{CaCl}_{2}$ without activated protein $\mathrm{C}$ (activated protein $\mathrm{C}$ resistance index).

DNA preparation and identification of the $1691, \mathrm{G} \rightarrow \mathrm{A}$ mutation in the factor $\mathrm{V}$ gene

Genomic DNA was prepared from peripheral blood leukocytes by a standard procedure. In brief, cells were lysed by mixing $100 \mu \mathrm{l}$ EDTA-blood samples with $500 \mu \mathrm{T}$ Tris/EDTA buffer $(10 \mathrm{mmol} / \mathrm{l}$ Tris- $\mathrm{HCl}, \mathrm{pH} 8.0$ and $1 \mathrm{mmol} / \mathrm{l}$ EDTA). The nuclei were pelleted by centrifugation for $10 \mathrm{~s}$ at $13000 \mathrm{~g}$. Supernatants were decanted and the procedure was repeated one to two times until clean nuclei pellets were obtained. The pellets were resuspended in $100 \mu$ lysis buffer containing $10 \mathrm{mmol} / 1$ Tris-HCl, $\mathrm{pH} 8.3,50 \mathrm{mmol} / 1 \mathrm{KCl}, 1.5$ $\mathrm{mmol} / 1 \mathrm{MgCl}_{2}, 0.1 \mathrm{~g} / 1$ gelatin and $5 \mathrm{~g} / \mathrm{l}$ Tween 20 . After adding $10 \mu \mathrm{l}$ proteinase $\mathrm{K}(10 \mathrm{~g} / \mathrm{l})$, the samples were incubated for $45 \mathrm{~min}$ at $56{ }^{\circ} \mathrm{C}$ followed by incubation for $10 \mathrm{~min}$ at $95^{\circ} \mathrm{C}$ to inactivate proteinase $\mathrm{K}$. DNA samples were stored at $-25^{\circ} \mathrm{C}$.

Allele-specific polymerase chain reaction was performed using primers recently described $(2,23)$ : Factor V FOR2 (5' consensus primer): 5' AGGAACAACAACATGATC 3'; Factor V NOR: 5' GGACAAAATACCTGTATTCCAC 3'; Factor V MUT: 5' GGACAAAATACCTGTATTCCAT 3'. Duplicate samples of genomic DNA from each individual were subjected to polymerase chain reaction with either the Factor V FOR2/Factor V NOR primer set specific for the "G" (normal) allele or the Factor V FOR2/Factor V MUT primer set specific for the " $A$ " (mutant) allele. The specificity of the allele-specific primers was extremely high by incorporation of an additional mismatch at the penultimate position (23). Polymerase chain reaction conditions were: $20 \mathrm{mmol} / \mathrm{l}$ Tris- $\mathrm{HCl}$, $\mathrm{pH} 8.4,50 \mathrm{mmol} / \mathrm{l} \mathrm{KCl}, 0.01 \mathrm{~g} / 1$ gelatin, $0.5 \mathrm{~g} / 1$ Tween $20,1.5$ $\mathrm{mmol} / 1 \mathrm{MgCl}{ }_{2}, 0.2 \mathrm{mmol} / 1$ of each dNTP, $0.5 \mu \mathrm{mol} / 1$ of each factor $\mathrm{V}$ related primer, $0.5 \mathrm{U} \mathrm{Taq}$ polymerase, and approx. $100 \mathrm{ng}$ genomic DNA in a final reaction volume of $25 \mu \mathrm{l}$. The samples were overlaid with $25 \mu \mathrm{l}$ mineral oil and thermocycling was performed using the thermocycler TR1 from MWG-Biotech (Ebersberg, Germany) with the following protocol: 1) $94^{\circ} \mathrm{C}, 2 \mathrm{~min}$ (hotstart denaturation); $57^{\circ} \mathrm{C}, 30 \mathrm{~s}$ (annealing); $72{ }^{\circ} \mathrm{C}, 30 \mathrm{~s}$ (extention) for one cycle and 2) $94^{\circ} \mathrm{C}, 15 \mathrm{~s} ; 57^{\circ} \mathrm{C}, 15 \mathrm{~s} ; 72^{\circ} \mathrm{C}, 30 \mathrm{~s}$ for the following 29 cycles. Products ( 224 base pairs) were separated by $2 \%$ agarose gel electrophoresis and visualized by ethidium bromide staining. Each DNA sample was analyzed twice.

\section{Results}

Reference values for the modified activated protein $\mathrm{C}$ resistance test

Determination of reference values for the activated protein $C$ resistance index was performed by testing 31 blood donors between the ages of 20 to 64 years, approximately corresponding to the ages of patients in the study. The 30 individuals without factor V Leiden muta- 
tion had indices between 1.7 and 2.1 (fig. 2a). The mean value $(\overline{\mathrm{x}})$ of the activated protein $\mathrm{C}$ resistance index was 1.9 , the standard deviation (SD) was 0.1 . The cutoff value determined as $\bar{x}-2 \mathrm{SD}$ was 1.7 . None of the blood donors without factor $\mathrm{V}$ Leiden mutation had an activated protein $\mathrm{C}$ resistance index lower than 1.7. One blood donor had an index of 1.4 and the genotype was heterozygous for the mutation.

\section{Comparison of the genotype test for factor $\mathrm{V}$} Leiden mutation with the modified functional test for activated protein $\mathrm{C}$ resistance

Blood samples from 104 patients with clinically suspected thrombophilia were tested for factor V Leiden mutation by allele-specific polymerase chain reaction. Definite signals were obtained in the DNA of homozygous normal patients as well as in patients heterozygous or homozygous for factor V Leiden (fig. 1). Eighty-six individuals $(82.7 \%)$ were normal, $15(14.4 \%)$ were heterozygous and three individuals $(2.9 \%)$ were homozygous for factor V Leiden (fig. 2b). Selecting the patients by the criterium "clinically manifested thrombosis", factor V Leiden mutation was detected in $32 \%$ of the individuals.

Using the modified activated protein $\mathrm{C}$ resistance test as described in Materials and Methods and the cutoff value of the activated protein $\mathrm{C}$ resistance index of 1.7, all patients without factor $\mathrm{V}$ Leiden were detected as normal in an index range between 1.7 and 2.5 with a mean

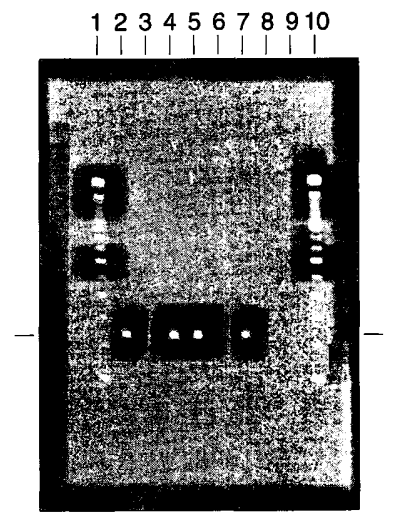

Fig. 1 Agarose gel electrophoresis of amplification products obtained by allele-specific polymerase chain reaction of factor $\mathrm{V}$ Leiden mutation.

Polymerase chain reaction was performed using specific pairs of primers for amplification of either the normal (wildtype) allele or of the mutant allele of factor V. Amplification products (224 base pairs) we stained by ethidium bromide. Tracks are as follows:

1 and 10: 100 base pairs ladder; 2 and 3: wildtype and mutation amplification of an individual without factor V Leiden mutation; 4 and 5: wildtype and mutation amplification of a heterozygous patient; 6 and 7: wildtype and mutation amplification of a homozygous carrier of factor Leiden mutation; 8 and 9: wildtype and mutation amplification of reagent controls without genomic DNA. Markers indicate the position of the specific 224 base pair amplification products. One of two identical polymerase chain reaction assays is shown.
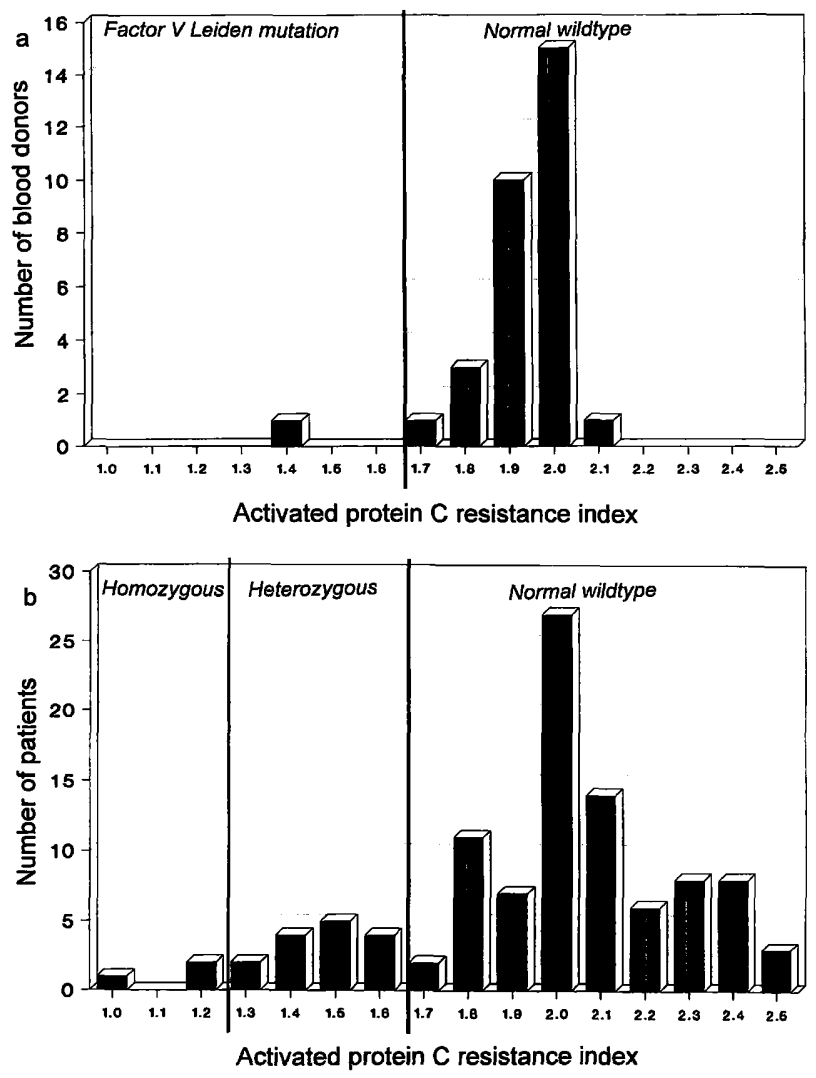

Fig. 2 Activated protein $\mathrm{C}$ resistance indices of blood donors and of patients with clinically suspected thrombophilia.

Activated protein $\mathrm{C}$ resistance indices of blood donors (a) and of patients with suspected thrombophilia (b) were determined as outlined in Materials and Methods. Molecular biology-based classification of individuals was performed as described in figure 1. Cutoff values were 1.7 for heterozygous and 1.3 for homozygous carriers of factor $\mathrm{V}$ Leiden mutation.

value of $2.1(\mathrm{SD}=0.2)$. Patients heterozygous for factor $\mathrm{V}$ Leiden had indices between 1.3 and 1.6 with a mean value of $1.5(\mathrm{SD}=0.1)$, whereas the three patients found homozygous for the mutation had activated protein $\mathrm{C}$ resistance indices of 1.0 and 1.2 (fig. 2b). One of these patients with an index of 1.2 suffered from acute lung embolism and therefore was under therapy with heparin when citrated blood samples were taken for the activated protein $\mathrm{C}$ resistance test.

\section{Discussion}

Venous thrombosis occurs with a prevalence of $1 / 1000$ individuals. The major reason for genetically determined thrombosis is resistance of coagulation factor $\mathrm{V}$ to activated protein $\mathrm{C}$ (activated protein $\mathrm{C}$ resistance), which is found in $20-60 \%$ of patients with venous thrombosis (1). At least $90 \%$ of cases of functional activated protein $\mathrm{C}$ resistance are caused by a single point mutation in the factor $\mathrm{V}$ gene named factor $\mathrm{V}$ Leiden $(1,4)$. We found activated protein $\mathrm{C}$ resistance/factor V Leiden in $17 \%$ of patients with suspected thrombophilia and in $32 \%$ of those with clinically manifested thromboembolic events. 
This is in line with the frequencies of factor $\mathrm{V}$ Leiden mutation reported by others (1-4). Patients homozygous for factor $\mathrm{V}$ Leiden mutation have also been shown to have a higher recurrence rate for thrombosis as compared with a control population (24). Thus, it seems to be indispensable for medical laboratories to offer tests for screening and verification of activated protein $\mathrm{C}$ resistance/factor V Leiden.

A definite method for detecting the mutation is the polymerase chain reaction. However, some protocols published so far are troublesome and can lead to equivocal results. On the other hand, testing of activated protein $\mathrm{C}$ resistance lacks specificity and sensitivity when using the conventional assay $(14,21,22)$. Whether the activated protein $\mathrm{C}$ resistance test in samples diluted with factor $\mathrm{V}$ deficient plasma provides clear-cut discrimination between normal wildtype and carriers of factor $\mathrm{V}$ Leiden mutation is still matter of debate $(15-20)$.

We adapted the activated partial thromboplastin timebased activated protein $\mathrm{C}$ resistance test with factor $\mathrm{V}$ deficient plasma dilution to a Schnitger-Gross coagulometer and were able to detect factor $\mathrm{V}$ Leiden mutation with a sensitivity and specificity of $100 \%$ in 104 patients and 31 blood donors. This is consistent with recent reports showing similar results from studies performed on fully automated coagulation systems that are not available in each medical laboratory $(17,18)$. In these studies the cutoff values for activated protein $\mathrm{C}$ resistance indices were between 2 and 2.5, whereas we found a cutoff value of 1.7 (determined by testing blood donors without the mutation) clearly discriminating patients without the mutation from heterozygous patients. Thus, it seems to be necessary that each laboratory determines its reference values for the activated protein $\mathrm{C}$ resistance index that refer to the analytical system and to the individual protocol used. The fact that in other hands the

\section{References}

1. Dahlbäck B. Resistance to activated protein $\mathrm{C}$, the $\mathrm{Arg}^{506}$ to Gln mutation in the factor $\mathrm{V}$ gene, and venous thrombosis. Thromb Haemost 1995; 73:739-42.

2. Kirschbaum NE, Foster PA. The polymerase chain reaction with sequence specific primers for the detection of the factor $\mathrm{V}$ mutation associated with activated protein $\mathrm{C}$ resistance. Thromb Haemost $1995 ; 74: 874-8$.

3. Rees DC, Cox M, Clegg JB. World distribution of factor V Leiden. Lancet 1995; 346:1133-4.

4. Bertina RM, Koeleman BPC, Koster T, Rosendaal FR, Dirven $\mathrm{RJ}$, de Ronde $\mathrm{H}$, et al. Mutation in blood coagulation factor $\mathrm{V}$ associated with resistance to activated protein $C$. Nature 1994; 369:64-7.

5. van Boven $\mathrm{HH}$, Reitsma PH, Rosendaal FR, Bayston TA, Chowdhury V, Bauer KA, et al. Factor V Leiden (FV R506Q) in families with inherited antithrombin deficiency. Thromb Haemost 1996; 75:417-21.

6. Kalafatis M, Lu D, Bertina RM, Long GL, Mann KG. Biochemical prototype for familial thrombosis. A study combining a functional protein $\mathrm{C}$ mutation and factor $\mathrm{V}$ Leiden. Arterioscler Thromb Vasc Biol 1995; 15:2181-7. modified activated protein $\mathrm{C}$ resistance test did not discriminate in each case (20) might depend on a lack of exact assay standardization, as was also observed in our hands when evaluating the test (not shown). Therefore, it might be useful to verify positive or questionable results of the activated protein $C$ resistance test, especially in the phase of test evaluation. The allele-specific polymerase chain reaction protocol described here proved to be reliable and easy to perform.

In the present study, a cutoff value for the activated protein $\mathrm{C}$ resistance index of 1.3 discriminated heterozygous from homozygous carriers of the mutation. However, the number of three individuals homozygous for factor V Leiden mutation was too small to allow a fundamental statement. The mean value of the activated protein $\mathrm{C}$ resistance index of blood donors without factor V Leiden was 1.9 , whereas the mean value in patients without carrying the mutation was 2.1 . The difference in mean values might be due to the fact that in contrast to healthy blood donors, the hospitalized patients were suffering from various diseases and as a rule were under drug treatment. Despite this, the cutoff determined by testing blood donors also strictly discriminated patients with or without the mutation.

It has been reported that the activated protein $\mathrm{C}$ resistance test with factor $\mathrm{V}$ deficient plasma is even valid in patients with oral anticoagulation or parenteral heparin therapy $(15-17,19,25)$. This is in line with our observation that one patient with intravenous application of heparin was detected accurately to be homozygous for factor $\mathrm{V}$ Leiden by the modified activated protein $\mathrm{C}$ resistance test.

\section{Acknowledgements}

The technical assistance of Marlene Slavik and Andrea Vinz is gratefully acknowledged.

7. Koeleman BPC, van Rumpt D, Hamulyak K, Reitsma PH, Bertina RM. Factor V Leiden: an additional risk factor for thrombosis in protein $\mathrm{S}$ deficient families? Thromb Haemost 1995; 74:580-3.

8. Zöller B, Berntsdotter A, Garcia de Frutos P, Dahlbäck B. Resistance to activated protein $C$ as an additional genetic risk factor in hereditary deficiency of protein S. Blood 1995; 85:3518-23.

9. Vandenbroucke JP, Koster T, Briet E, Reitsma PH, Bertina $\mathrm{RM}$, Rosendaal FR. Increased risk of venous thrombosis in oral-contraceptive users who are carriers of factor $\mathrm{V}$ Leiden mutation. Lancet 1994; 344:1453-7.

10. Bridey F, Wolff M, Laissy JP, Morin V, Lefebvre M, de Prost D. Fatal cerebral venous sinus thrombosis associated with the factor $\mathrm{V}$ Leiden mutation and the use of oral contraceptives. Thromb Haemost 1995; 74:1382.

11. Rosendaal FR. Oral contraceptives and screening for factor $\mathrm{V}$ Leiden. Thromb Haemost 1996; 75:524-5.

12. Dahlbäck B, Carlsson M, Svensson PJ. Familial thrombophilia due to a previously unrecognized mechanism characterized by poor anticoagulant response to activated protein $\mathrm{C}$ : prediction 
of a cofactor to activated protein C. Proc Natl Acad Sci USA 1993; 90:1004-8.

13. de Ronde H, Bertina RM. Laboratory diagnosis of APC resistance: a critical evaluation of the test and the development of diagnostic criteria. Thromb Haemost 1994; 72:880-6.

14. Hassett C, Faruki H, Bontempo FA. An evaluation of APC resistance and factor $V$ Leiden in an unselected patient population. Blood 1995; 86:915a.

15. Jorquera JI, Montoro JM, Fernandez MA, Aznar JA, Aznar J. Modified test for activated protein C resistance. Lancet 1994, 344:1162-3.

16. Trossaert M, Conard J, Horrellou MH, Samama MM, Ireland $\mathrm{H}$, Bayston TA, et al. Modified APC resistance assay for patients on oral anticoagulants. Lancet 1994; 344:1709.

17. Engel H, Zwang L, van Vliet HH, Michiels JJ, Stibbe J, Lindemans $\mathrm{J}$. Phenotyping and genotyping of coagulation factor $\mathrm{V}$ Leiden. Thromb Haemost 1996; 75:267-9.

18. Gouault-Heilmann M, Leroy-Matheron C. Factor V Leidendependent APC resistance: improved sensitivity and specificity of the APC resistance test by plasma dilution in factor V-depleted plasma. Thromb Res 1996; 82:281-3.

19. Cadroy Y, Sie P, Alhenc-Gelas M, Aiach M. Evaluation of APC resistance in the plasma of patients with Q506 mutation of factor V (factor V Leiden) and treated by oral anticoagulants. Thromb Haemost 1995; 73:734-5.

20. Trossaert M, Conard J, Horellou MH, Elalamy I, Samama, MM. The modified APC resistance test in the presence of factor $\mathrm{V}$ deficient plasma can be used in patients without oral anticoagulant. Thromb Haemost 1996; 75:521-2.

21. Leroy-Matheron C, Levent M, Pignon JM, Mendonca C, Gouault-Heilmann $\mathrm{M}$. The $1691 \mathrm{G} \rightarrow \mathrm{A}$ mutation in the factor $\mathrm{V}$ gene: relationship to activated protein $\mathrm{C}$ (APC) resistance and thrombosis in 65 patients. Thromb Haemost 1996; 75:4-10.

22. Zehnder JL, Benson RC. Sensitivity and specificity of the APC resistance assay in detection of individuals with factor $\mathrm{V}$ Leiden. Am J Clin Pathol 1996; 106:107-11.

23. Bellissimo DB, Kirschbaum NE, Foster PA. Improved method for factor V Leiden typing by PCR-SSP. Thromb Haemost 1996; 75:520.

24. Rintelen C, Pabinger I, Knoebl P, Lechner K, Mannhalter C. Probability of recurrence of thrombosis in patients with and without factor V Leiden. Thromb Haemost 1996; 75:229-32.

25. Kraus M, Zander N, Fickenscher K. Coagulation assay with improved specificity to factor $\mathrm{V}$ mutants insensitive to activated protein $C$. Thromb Res 1995; 80:255-64.

\section{Received July 19/November 18, 1996}

Corresponding author: Dr. Karl H. Reuner, MedizinischDiagnostisches Institut, Klinikum Karlsruhe, Moltkestraße 90 , D-76133 Karlsruhe, Germany 
